\title{
Participating in the Co-creation of the New Narrative regarding European Identity through European Capitals of Culture
}

\author{
Codruța-Diana Simionescu ${ }^{1}$
}

\section{Introduction}

There is an on-going debate surrounding the concepts of European identity and the sense of belonging, especially for people living in Europe, in the light of recent events such as the United Kingdom leaving the European Union, the rise in populism and the wave of rage against immigrants in some European countries. Another phenomenon, which cannot be ignored anymore, is the continuous numerical change in the structure of the world population. In the past 115 years, the population in Europe registered a decline from $25 \%$ in 1900 , to $6 \%$ in 2015 , as related to the entire world's population. Forecasts are not optimistic: in 2060 , Europe's population could reach $4 \%$ of the entire population of the globe ${ }^{2}$. Increasing migration, the demographic decline in some parts of the globe, population structure changes, and multiculturalism tend to isolate us from our cultural heritage. ${ }^{3}$ In this paper, we refer to cultural heritage as a cultural and social process, a discursive construction, through which we assign value and meaning to our surrounding space. ${ }^{4}$ Moreover, according to UNESCO's manual for the management of cultural heritage, there is a shift towards viewing the heritage audiences

\footnotetext{
${ }^{1}$ Faculty of Political Sciences, Philosophy and Communication Sciences, West University of Timişoara, Romania.

2 Sources: Eurostat, https://ec.europa.eu/eurostat/databrowser/view/tps00001/ default/table?lang=en and UNO statistiques: https://unstats.un.org/unsd/demogra phic/sconcerns/population/default.htm.

${ }^{3}$ J. Skrzypaszek, "Intangible Heritage and its Role in the Formation of Social and Personal Identity," Heritage (2012): 1491-1497.

${ }^{4}$ L. Smith, Uses of Heritage (New York: Routledge, 2006), 13.
} 
"as active agents in the mediation of the meanings of heritage." 5 Cultural heritage gives people meaning, a sense of identity and offers relevance to their daily lives.

In Europe, the most ambitious project of bringing together several states under the same dome is the European Union itself. Although the European Union does not include the entire European space, it is an ecosystem of several different languages, cultures and traditions. At this moment, the EU is an unfinished project and the interest in creating a common European identity that preserves national identities is at the core of this project. Martinelli stresses that this unification should be based on shared loyalty and a commitment to the same cultural values. ${ }^{6}$

Asking ourselves "What does it feel to be European?" is a legitimate question, a starting point for exploring our shared cultural heritage as a source of overcoming the EU crisis, as well as an encouragement to think critically about European heritage and identity. ${ }^{7}$ Delanty argues for a different approach in considering and understanding Europe's cultural heritage: "a transnational approach," based on the central argument of "entanglement" of European and non-European cultures, an interaction of histories and memories with a transformative effect upon cultures. ${ }^{8}$

In light of the above statements, this paper intends to examine how the intrinsic value of culture helps to develop a new narrative regarding European identity and new maps of meaning inside a cross-border region. We focus on the future European Capitals of Culture (ECoCs): Timișoara 2021 (Romania) and Novi Sad 2021 (Serbia). An extensive part of our research implies an auto ethnographic undertake and the ethnotextuality method. ${ }^{9}$

Some of the hypotheses we start from in this paper originate in a systematic observation (qualitative observation) undertaken as a cultural

5 V. Vujicic-Lugassy and L. Frank, Managing World Cultural Heritage (UNESCO/ ICCROM/ICOMOS/IUCN., 2013).

${ }^{6}$ A. Martinelli, "The European Identity," Glocalism. Journal of Culture, Politics and Innovation 2 (2017).

${ }^{7}$ C. Whitehead, "Do You Feel European?", in Tecmen, Ayşe (ed.), CoHere Education, Heritage and Identities in Europe: Understanding Europe's current predicaments (Horizon 2020 project, European Union, 2018), 1-9.

${ }^{8}$ G. Delanty, The European Heritage: a Critical Re-interpretation (London: Routledge, 2018), $1-17$.

${ }^{9}$ G.-O. Gabor, “The Autoethnographic Undertaking: A Day in Ron Pelias' Life," Sage Journals. Qualitative Inquiry (2019): 1-14. 
mediator or participant in: focus groups (before and after Timișoara won the ECOC title), cultural cafes, cultural mediation and management workshops (organized by Timişoara 2021 Association and local cultural NGOs), presentations of European cultural networks (Culture Action Europe, European Network of Cultural Centres, Like - Les Rencontres Association) and a six months Erasmus research programme for writing my $\mathrm{PhD}$ thesis in Novi Sad, Serbia in 2017. We applied qualitative content analysis on following documents regarding the ECoC: European legislative papers, relevant reports of past successful ECoCs, Timişoara2021 and Novi Sad2021 bid books, pre-selection, selection and monitoring reports, press and official web sites of Timișoara2021 and Novi Sad2021 and made a review of the relevant academic literature on the researched subject.

\section{II. "Interweaving Narratives", metaphors and European identity}

In postmodern times, as Lyotard emphasizes, there is a dissolution and disintegration of the social bond, into "a mass of individual atoms", placed at the nodal points of a communication network. The individual becomes a receiver, sender or referential of different messages, in a society that values communication. ${ }^{10}$ If for modernity, knowledge builds reality (Kant), in the postmodern era, communication has this role. There is the fact that we live in a culture of communication (a new imperialism) and we have the mission to understand ourselves and the others and, in the same time, to seek the truth. Moreover, in postmodern times, communication is meant to build relationships. The communication process called meta-communication, like Paul Watzlawick states, has besides content, the relationship aspect and the content becomes clear in the light of that relationship. ${ }^{11}$

Within the public space, according to Habermas, communication takes two forms: the communicative action or interaction and the discourse. In the communicative action, there is an exchange of information through the statements each person is uttering, and the validity of these correlations relating to the meaning of the statements is assumed in a naïve manner, without the slightest substantiation. On the

\footnotetext{
${ }^{10}$ J.-F. Lyotard, La condition postmoderne: rapport sur le savoir (Paris: Minuit, 1979).

11 A. Codoban, Body, Image and Relationship. From Culture of knowledge to Culture of Communication (Saarbrücken: Lambert Academic Publishing, 2013).
} 
other hand, in case of the discourse, no information is exchanged and we are dealing with a problem of validity on certain topics. In this case, the agreement is produced and substantiated in a narrative manner. In discourse, consensus refers to both the propositional content of statements/expressions (opinions) and the expected behaviour (norms). ${ }^{12}$ In his ontological analysis of reality, Searle understands narration as a social act and narratives as social products. ${ }^{13}$

Postmodernism as stated by Lyotard is favourable to narratives in a certain sense, but not to the "Grand Narratives". The relativism of values and cultivation of amalgam urge us to give things a meaning through micro-stories of legitimation. Story-telling, as this narrative practice is known, involves the application of narrative processes to enhance the public acceptance of a discourse. Possible areas of use are: advertising, marketing, especially creative industries, cultural mediation, services, politics or project management. Moreover, the viral effect of media has helped to increase the power of the story. The story is based on emotion, but the narrative, the discursive side, is also important. Fishers' Narrative Paradigm states that all meaningful communication takes place through storytelling or events reporting. People are born storytellers. Human beings participate as narrators and observers of narratives. This theory further argues that stories are more compelling than arguments. ${ }^{14}$

Lakoff, starting from the assumption that "life is a story", explains that human beings construct coherent narratives about their lives, following certain features: participants, parts, stages, causal connections, plans and goals. We think and act according to a conceptual system based on metaphors. ${ }^{15}$ The communicative field is borrowed from the philosophical discourse communication through metaphors. On the same line, Mihaela Tudor states that the significant change of the angle of view on the metaphor leads us to a new way of understanding the role of the metaphor, as a mediation between real situations of communication, employed in discourses from different fields, whether in the field of political communication, branding, advertising, public or

\footnotetext{
12 J. Habermas, The Theory of Communicative Action, Volume 1 (Boston: Beacon Press, 1984). 13 J. Searle, The Construction of Social Reality (New York: Free Press, 1995).

14 W. Fisher, "The Narrative Paradigm: An Elaboration," Communication Monographs 52 (1985): 347-367.

15 G. Lakoff and M. Johnsen, Metaphors we live by (London: The University of Chicago Press, 2003).
} 
organizational communication. Understanding and describing communication problems in contemporary society demand the identification and analysis of the typologies of metaphors encapsulated in the socio-cultural process itself. When it comes to understanding metaphors, we must speak about them, as an action of someone who does something for a certain purpose. ${ }^{16}$ Experiments conducted in the psychological field reinforced the assumption that we talk about "complex and abstract ideas" using metaphors. When we refer to "important societal issues," metaphors have a great influence on our process of conceptualization and our action. ${ }^{17}$

Shore, on the same consideration, suggests that "metaphors are central to the process of imagining and conceptualising Europe" and their function is "far from being simply window-dressing used to embellish the political process with colourful imagery". There is a close link between the depiction of the European integration process through metaphors and the evolution of the political process. "The old mechanistic, architecture metaphors" (the European construction, the process of building) have been gradually replaced in the narrative of the EU's institutions with "metaphors concerned with relationships" (feeling of belonging, collective solidarity). Consequently, at the linguistic level, that transition pictures the European integration process as a "humanistic and cultural enterprise."18

As we have stated from the beginning of this research, European Union is not the only actor responsible for shaping a European Narrative and European identity. At institutional level, the Council of Europe, as Monica Sassatelli emphasizes, "provided the evolving EU with narratives and symbols". Besides that, numerous active agents, such as: "networks, associations, individuals" have the role of promoting, shaping and legitimation of those symbolic representations, as well as acting as interpreters of the institutional narratives. ${ }^{19}$

16 M.-A., Tudor, Epistémologie de la communication. Science, sens et métaphore (Paris: L'Harmattan, 2013)

${ }_{17}$ P. H. Thibodeau, L. Boroditsky, "Metaphors We Think With: The Role of Metaphor in Reasoning," PLOS ONE 6 (2011): e16782.

18 C. Shore, "Methaphors of Europe: Integration and the Politics of Language," in Antropology and Cultural Studies, ed. Stephen Nugent and Cris Shore (Pluto Press, 1997).

19 M. Sassatelli, Becoming Europeans. Cultural identities and cultural policies (Basingstoke: Palgrave Macmillan, 2009), 20. 
In April 2013, Jose Manuel Barosso, then the president of the European Commission, gave a speech launching the New Narrative project. The core reason of the project was "to continue to tell the story of Europe" for future generations. The European Union's history began with the "reconciliation between long-standing enemies" after the Second World War, being a solution to overcome division in Europe. The rising wave of populism and nationalism in Europe, as well as the "indifference of many pro-Europeans" asked for a similar action, a mediation "between the people of Europe and the European Union". The appeal to the "world of culture" to contribute to this project started from the assumption, as Mr. Barroso stated, that the European Union was "fundamentally a political and cultural project based on strong humanist values". ${ }^{20}$

Artists, writers and scientists made a contribution to a new book, The Mind and Body of Europe: A New Narrative. The preface, entitled 'Interweaving Narratives', signed by President Barroso, pointed out how the New Narrative project opened a public space for debate and gave the opportunity to voices from different cultural and scientific spheres to articulate their idea of Europe. Debates were held across Europe and members of the European Commission held citizen dialogues. ${ }^{21} \mathrm{~A}$ New Narrative website had been created. Today, the website is still there, although there are not any recent updates. Europe, as a "state of mind" 22 project, was aiming to create a strong sense of European identity.

\section{The value of culture and maps of meaning regarding the European Union}

According to Holden, culture is seen as having an intrinsic, instrumental or institutional value. ${ }^{23}$ When thinking about the importance of culture for individuals and society at large, specialists refer to cultural value as "the ability of arts and cultural experience to help shape reflective

\footnotetext{
20 Speech by President Barroso: "A new narrative for Europe", online: https://ec.europa.eu/commission/presscorner/detail/en/SPEECH_13_357

21 The mind and body of Europe: a new narrative, ed. Emiliano Battista et al. (Luxembourg: Publications Office of the European Union, 2014).

22 The Mind and Body of Europe: A New Narrative, online: https://ec.europa. $\mathrm{eu} /$ assets/eac/culture/policy/new-narrative/documents/declaration_en.pdf.

23 J. Holden, "Cultural Value and the Crisis of Legitimacy," Demos, Open Access (2006): 14-16.
} 
individuals". Through the cultural engagement process, individuals enhance their reflectiveness and understand themself both as cognitive and affective agents. ${ }^{24}$ Postmodern revolutions lead to a growing need for individuals to understand themselves and their world, a problem also faced by the educational system, in search of a model to rebuild our fragmented world. Such an integrative model should take into account the following dimensions: the affective (I-subject), cognitive (rational self), social (social, collective self) and the ideological (cultural and educational values) dimension. ${ }^{25}$

Our social and cultural resources are crucial for the process of creating meaning. A humanistic education, as Daniela Dumitru argues, increases the scores of critical thinking dispositions of students, when these dispositions are tested. The creation of meaning implies a process of negotiation, mediation, in which students are confronted with different views and have to understand others' perspectives. The creation of meaning is the result of the creative thinking process, as well as the critical thinking one. ${ }^{26}$

Although in terms of reasoning, people have common views, when examining the critical thinking skills of each party, there are observable differences that can be mapped in the form of patterns. The sum of mental patterns shapes a mental map that is influenced by one's own thinking, as a result of his/her personal, social and professional experience. ${ }^{27}$ The identification of these mental maps plays an essential role in the process of cultural mediation and in the experimentation of cultural heritage by each individual.

Cultural mediation process facilitates access to the experimentation of cultural heritage, for those who live a feeling of exclusion, create a space for their voices to be heard and search in the same time to identify the motivation and drive of the passive audiences in order to actively

${ }^{24}$ G. Crossick \& P. Kaszynska, Understanding the value of arts \& culture. The AHRC Cultural Value Project (Swindon: Arts and Humanities Research Council, 2016), 42-43.

25 J.-P. Pourtois and H. Desmet, L'éducation postmoderne (Paris: Presses Universitaires de France, 1997), 50-51.

26 D. Dumitru, "Creating meaning. The importance of Arts, Humanities and Culture for critical thinking development," Studies in Higher Education 44 (2019): 870-879.

${ }^{27}$ G. Clitan, "Gândirea critică - o geografie mentală a omului de rând (?) [Critical thinking - a mental geography of the common people]," In Taraburca, Emilia (ed.). Geografii mentale: timpuri și spații ale memoriei europene [Mental geographies: times and spaces of European memory] (Chișinău: CEP USM, 2017). 
engage them in the experimentation of cultural heritage. The ultimate goal of cultural mediation is to create a culture of sharing and the development of reflexivity and empathy in the audience. The process of reflecting on the treasured memory from the past has an effect on readjusting our identity, in accordance to a certain space and contemporaneous time. ${ }^{28}$

Despite crises of all kinds, of linguistic, ethnic and national diversity, culture is the dome that brings together all European states, whether a member of the European Union or not. To counteract the growing disparities regarding development among the Member States, in 1985, the European Union decided to award a prize to one city in Europe, a different city each year, for cultural performances. That was the commencement of the European Capital of Culture title. The prize was originally awarded as the City of Culture.

Jacques Delors, then President of the European Commission, stated in Strasbourg on a presentation about the European Commission's policy, held on January 17-18, 1989, that "no one can fall in love with the common market" 29 . In 1985, when he had been appointed to office, he mentioned that one of the challenges of the European Economic Community was civilization. In that context, there was a need to reaffirm the European values and merge the aspirations, sometimes contradictory of his contemporaries, into new constructions. Over four years, that challenge was still present. Delors referred to Fernand Braudel, a lucid observer of the integration movements of the early 1960s:

"It would be wrong for human nature to serve only harmless sums; they seem to fade when they are put together with the impetuous enthusiasm, though not always unreasonable, the enthusiasm that has mobilized Europe in the past. Can a European conscience be built on figures only? Or is not consciousness exactly what the figures might fail to surprise, the consciousness that can develop in ways that cannot be calculated?"

As a result, Delors believed that it was time to put "some flesh on the bones of the Community" and to give it "more soul". Similarly, the founder of the European Union, Jean Monnet, said that if he were to

\footnotetext{
${ }^{28}$ C.-D. Simionescu, Heritage, “Identity and Cultural Mediation, " Hermeneia 21 (2018): 95-104.

29 Jacques Delors's presentation, https://op.europa.eu/en/publication-detail/-/publi cation/59acf3b9-04e2-4dc2-a031-dd1b7e9c6c32/language-en.
} 
start the project again, he would start with culture. Thus, the prize that initially rewarded cultural performances became a cultural mediation program, meant to open the community to new forms of art, co-creation and engagement of new audiences.

\section{The European Capital of Culture title in a cross-border region: Timişoara 2021 (Romania) and Novi Sad 2021 (Serbia)}

The transnational characteristics of the European identity and the entanglement of the European cultures might be observed through the analysis of the European dimension of the selected ECoC programmes. First, through the European dimension, the jury evaluates the intended cooperation of the candidate city with other cultural operators, artists and other cities from EU member states. Secondly, it emphasizes the richness of cultural diversity in the EU. Thirdly, its purpose is to bring together the common features of the European cultures. This criterion has, as a central objective, to raise awareness among the population of a given country about the cultural diversity in Europe. ${ }^{30}$ Analysing the European dimension of an ECoC in a cross-border region shows "how the ECoC goals are articulated and what impacts are planned in this specific territorial context." 31

Following Sibiu200732, in 2016 Timișoara was designated by a panel of juries the European Capital of Culture. There is an unprecedented event in the history of the European Capital of Culture program, since 1985, when two cities, which are situated at a close distance $(146 \mathrm{~km}$ between Timişoara and Novi Sad), have won this title. Moreover, if we consider the other city, which holds the title of European Capital of Culture in 2021, Eleusis of Greece, the focus is on the Balkan region. Being born in the Balkans has a special connotation, sometimes "sweet"

\footnotetext{
30 No. 622/2006/EC, Decision of European Parliament and Council regarding action for the European Capital of Culture event.

${ }^{31}$ C. Turșie, "A research agenda to assess the social and cultural impacts of the European Capital of Culture programme in cross-border regions," paper presented at the International Colloquium of the Regional Science Association of French Language and Romanian Association of Regional Sciences, 4-6 July 2019, Iași, Romania.

32 Sibiu ECC 2007, https://eur-lex.europa.eu/legal-content/EN/TXT/PDF/?uri= CELEX:52009DC0689\&from $=\mathrm{EN}$.
} 
and sometimes "bitter", as the metaphorical significance of the name itself ("ball" means honey and "kan" blood in Turkish). ${ }^{33}$

The first round for selecting the ECoC city in Romania took place in 2015 and fourteen candidate cities applied for the title. The concept of the cultural programme presented by Timișoara 202134, "Shine your light! Light up your city!" was centred on the audience engagement. It was a metaphor of a journey that offered the opportunity to move from loneliness to belonging, from dark areas to the light. The traveller was supposed to pass six stations, on eighteen routes, under three territories. The territories were, in fact, the sum of the challenges encountered today in Europe, namely: People, Places and Connections. Passivity is a major issue in today's Europe. The cultural strategy presented aimed to work with emergencies to reactivate that passive civic energy. Through the cultural program, the cultural actors and institutions, at local and national level, wanted to create an environment that stimulated and generated a proactive civic engagement. The slogan "Light up your city!" had the role of motivating the inhabitants of Timișoara to turn their eyes towards the city they lived in and engage in its transformation. Reflection and development of attachment towards a place are sources of motivation and drive for renewing someone's identity.

The European dimension, as the bidbook of Timișoara 2021 underlines, is a frame for the whole "transformational process", the Journey mentioned above, at the individual and community level, towards more contemporaneous "values and challenges". The European themes of the cultural programme are, to mention just a few: discrimination due to sexual orientation, the linguistic diversity in today's Europe, Holocaust, youth unemployment, enmity towards newcomers or migrants. Another indicator of the European dimension regards "the international partnerships". Timișoara places a special attention on the cooperation through cultural projects with the neighbouring countries, Serbia and Hungary and brings to the fore the cultural infrastructure of the former Banat region. The Bega Canal extends towards the Danube River, which is crossing ten European countries and, that way, facilitates

33 E. Ilieva, "An Intercultural Program from a Balkan Perspective," in Citizenship, Democracy and Lifelong Learning, ed. Medel-Añonuevo, Carolyn and Mitchell, Gordon (Hamburg: UNESCO Institute for Education, 2003), 169-174.

34 TM2021 Bidbook Cultural Programme, Timișoara, European Capital of Culture Association, 2015. 
the involvement of an extensive transnational cultural network. The selection panel underlined that Timișoara was expected to set "a considerable range of partnerships with Novi Sad and Elefsina.

The Novi Sad 2021 cultural programme ${ }^{35}$ aims at mediating among countries that were at war in the recent past and reconcile past memories with the present. From this objective comes off the three main themes connected with the conflict resolution area: the heritage of diversity in the area as a useful resource for "intercultural dialogue", learning "the culture of dialogue" and "the art of peace". The artistic content of the programme, built as four bridges ("New Way", the "Rainbow", the "Freedom" and the "Hope") envisages the dynamic and flexible meaning of the trust-building process.

The intention of Novi Sad to cooperate with Rijeka2020 and Timişoara 2021, as well as the cooperation with former ECoCs from the region, strengthen the ECoC effect on long term. As a candidate country, Serbia sees the benefits of the public debate on the European Union generated in the ECoC framework.

\section{Conclusion}

The ECoC programmes in a cross-border region, through the metaphors encapsulated in their central concept, facilitate a space of reflection for individuals and communities on European cultural heritage and present challenges of Europe, highlighting their shared features. The ultimate goal is to perceive the transnational touch of the European identity and the entanglement of cultures inside the European space and to shape new mental maps in accordance with a contemporaneous time.

\section{References}

Battista, Emiliano, Nicola Setari, and Els Rossignol. The mind and body of Europe: a new narrative. Luxembourg: Publications Office of the European Union, 2014.

Clitan, Gheorghe. "Gândirea critică - o geografie mentală a omului de rând (?) [Critical thinking - a mental geography of the common people]." In Geografii mentale: timpuri și spații ale memoriei europene

\footnotetext{
35 Novi Sad 2021 European Capital of Culture Candidate City, Bidbook, Novi Sad, City of Novi Sad, 2016.
} 
[Mental geographies: times and spaces of European memory], ed. Emilia Taraburca. Chișinău: CEP USM, 2017.

Codoban, Aurel. Body, Image and Relationship. From Culture of knowledge to Culture of Communication. Saarbrücken: Lambert Academic Publishing, 2013.

Crossick, Geoffrey and Patrycja Kaszynska. Understanding the value of arts \& culture. The AHRC Cultural V alue Project. Swindon: Arts and Humanities Research Council, 2016.

Delanty, Gerard. The European Heritage: a Critical Re-interpretation. London and New York: Routledge, 2018.

Dumitru, Daniela. "Creating meaning. The importance of Arts, Humanities and Culture for critical thinking development." Studies in Higher Education 44 (2019): 870-879.

Fisher, Walter. "The Narrative Paradigm: An Elaboration." Communication Monographs 52 (1985): 347-367.

Gabor, Georgina Oana. "The Autoethnographic Undertaking: A Day in Ron Pelias' Life.” Sage Journals. Qualitative Inquiry (2019): 1-14.

Habermas, Jürgen. The Theory of Communicative Action, Volume 1. Boston: Beacon Press, 1984

Holden, John. "Cultural Value and the Crisis of Legitimacy." Demos, Open Access (demos.co.uk) (2006): 14-16.

Ilieva, Emilia. "An Intercultural Program from a Balkan Perspective.” In Citizenship, Democracy and Lifelong Learning, ed. Carolyn MedelAñonuevo and Gordon Mitchell. Hamburg: UNESCO Institute for Education, 2003.

Lakoff, George and Mark Johnsen. Metaphors we live by. London: The University of Chicago Press, 2003.

Lyotard, Jean-François. La condition postmoderne: rapport sur le savoir. Paris: Minuit, 1979.

Martinelli, Alberto. "The European Identity." Glocalism. Journal of Culture, Politics and Innovation 2 (2017).

Pourtois, Jean-Pierre and Huguette Desmet. L'éducation postmoderne. Paris:

Presses Universitaires de France, 1997.

Sassatelli, Monica. Becoming Europeans. Cultural identities and cultural policies.

Basingstoke: Palgrave Macmillan, 2009.

Searle, John. The Construction of Social Reality. New York: Free Press, 1995. 
Shore, Cris. "Methaphors of Europe: Integration and The Politics of Language." In Antropology and Cultural Studies, ed. Stephen Nugent and Cris Shore. Pluto Press, 1997.

Simionescu, Codruța-Diana. "Cultural Heritage, Identity and Cultural Mediation." Hermeneia 21 (2018): 95-104.

Skrzypaszek, John. "Intangible Heritage and its Role in the Formation of Social and Personal Identity." Heritage (2012): 1491-1497.

Smith, Laurajane. Uses of Heritage. New York: Routledge, 2006.

Thibodeau, Paul H. and Lera Boroditsky. "Metaphors We Think With: The Role of Metaphor in Reasoning.” PLoS ONE 6 (2011): e16782. Tudor, Mihaela-Alexandra. Epistémologie de la communication. Science, sens et métaphore. Paris: L'Harmattan, 2013.

Turșie, Corina, "A research agenda to assess the social and cultural impacts of the European Capital of Culture programme in crossborder regions." Paper presented at the International Colloquium of the Regional Science Association of French Language and Romanian Association of Regional Sciences Les territoires face au défi de la durabilité. Regards croisés Est-Ouest et Sud-Nord, section Cross-Border European Capitals of Culture and sustainable urban development. 4-6 July 2019, Iași, Romania

Vujicic-Lugassy, Vesna and Laura Frank. Managing World Cultural Heritage. UNESCO/ICCROM/ICOMOS/IUCN, 2013.

Whitehead, Christopher. "Do You Feel European?" In CoHere Education, Heritage and Identities in Europe: Understanding Europe's current predicaments, ed. Ayşe Tecmen. Horizon 2020 project, European Union, 2018.

\section{Other sources}

Eurostat: https://ec.europa.eu/eurostat/databrowser/view/tps00001/ default/table?lang=en.

Jacques Delors's presentation, https://op.europa.eu/en/publicationdetail/-/publication/59acf3b9-04e2-4dc2-a031-dd1b7e9c6c32/lang uage-en.

No. 622/2006/EC, Decision of European Parliament and Council regarding action for the European Capital of Culture event.

Novi Sad 2021 European Capital of Culture Candidate City, Bidbook, Novi Sad, City of Novi Sad, 2016.

Sibiu ECC 2007, https://eur-lex.europa.eu/legal-content/EN/TXT/ $\mathrm{PDF} /$ ?uri=CELEX:52009DC0689\&from $=\mathrm{EN}$. 
Speech by President Barroso: "A new narrative for Europe", online: https://ec.europa.eu/commission/presscorner/detail/en/SPEECH _13_357.

The Mind and Body of Europe: A New Narrative, online: https://ec.europa.eu/assets/eac/culture/policy/new-narrative/doc uments/declaration_en.pdf.

TM2021 Bidbook Cultural Programme, Timișoara, European Capital of Culture Association, 2015.

United Nations Organisations statistics: https://unstats.un.org/unsd/ demographic/sconcerns/population/default.htm.

\section{Acknowledgements}

This paper was supported by the research project PATCULT\#RO Complex multidisciplinary platform for integrative and systematic research of tangible and intangible identities and cultural heritage in Romania, PN III-P1-1.2-PCCDA-2017-0686, 52PCCDI/2018, funded by UEFISCDI. 